\title{
THE BULGARIAN AIR FORCE IN A NEW SECURITY ENVIRONMENT
}

\author{
Brigadier General Mark O. SCHISSLER
}

\begin{abstract}
Military leaders have to consider political and economic realities and explore efficiency options, such cooperation and partnership, in calling for and advancing air capabilities.
\end{abstract}

Keywords: imperfect information, force planning, airpower, transformation, acquisition.

\section{Introduction}

Distinguished participants, it has been my pleasure to speak to several AFCEA events in Washington DC, Germany, and now Bulgaria. I am especially pleased to be in Plovdiv where this week USAFE C-130Js are flying a joint training event with Bulgarian Air Force C-27 aircrews focusing on NVG operations, airland and SOF airdrop skills. This C-130 event was guided by a bilateral engagement strategy study we conducted with the Bulgarian Air Force just five weeks ago, is part of larger effort designed to advance the capabilities of both. That engagement strategy study is being used to develop a five year bilateral engagement plan and is now the HQ USAFE benchmark for international partnering efforts. That same study will drive the military partnering objectives for an F-15C deployment to Graf Ignatievo Air Force Base in May 2010.

\section{Political, Economic, and Military Issues}

May you live in interesting times

Chinese curse

We do, and these are very interesting times politically. We may remember the late '80s and early '90s as dynamic times, but it seems we are again in uncharted waters that could bring instability. We’ve recently seen traditionally stable and prosperous European countries go through political and economic upheaval. Issues such as em- 
ployment, migration, demographic trends, and flexible access to affordable energy sources are to be MAJOR looming issues that will impact every country. We have sharp political divides in many of our countries as elected governments do their best to deal with these issues. These changes pressure the fabric of the great political and economic interoperability construct known as the European Union.

The political reality in 2010 is very much influenced by the economic realities we are experiencing. The financial crisis that started in the United States was followed by all kinds of second and third-order effects around the world. Our national economies are related and interdependent; we have invested in each other and are affected by the success or failure of nations half a world away. What happens in the European Union will affect every country in Europe (and several other countries), even those not currently EU members. We are involved in this together - call it an interdependent and interoperable economy. That interdependence and interoperability has had a positive influence on all our standards.

We are currently witnessing a good example of how interdependent our economies are in the fiscal state of Greece, Portugal, Spain, and others. We see significant effort by EU states such as Germany and institutions like the IMF to limit instability. We can see daily proof that as nations make good-faith economic, political, and military choices, the fact is we act on imperfect information and world markets are a lot messier than we believe. ${ }^{1}$ So how long will it take to see real recovery? Some say another five or ten years, and that assumes we do not hit any more.

I am not an economist; I do not even balance my own checkbook, but I do know that memories are short!! I am also not a political scientist, but I do know when the economic trend is down, everyone's attention—government and citizen—turns inward people vote with their wallets!

So I am not an economist and I am not a political scientist. I am an experienced military officer and would like to turn to how we ensure our security structures based on NATO interdependence and interoperability can continue to provide stability on the national security front even as we face instability and the unknown in other areas.

We as military leaders are affected directly by politics and the economy. We have all seen dramatic reductions in the percentage our nations can and will spend on military weapons and hardware in bad times. At the same time, we find ourselves challenged by non-state actors with asymmetric strategies, often spending 5-10 percent of what we spend and gaining ground against conventional forces.

Al Qaeda has as part of their strategy to weaken the U.S. economy as a means to get us out of the fight against extremism. Desert Storm taught all our future enemies not to meet us on the conventional field of military battle. Weapons, aircraft, ships and 
C2 systems all cost a lot. We have to make careful choices to ensure that stability with continued NATO interdependence and NATO interoperability; that is what this meeting today is all about.

\section{Military Acquisition}

All that considered, it is clear the development of air power capabilities must be considered within the broader context of national and alliance strategic goals and objectives. We all need a long term vision to drive the acquisition choices. NATO's new strategic concept will provide an overarching vision of future roles/missions of the Alliance and should influence development of strategic guidance within Bulgaria. Decisions regarding how to balance the demands of expeditionary operations and collective defense need to be addressed by both the Alliance and Bulgaria. A willingness to invest in collaborative security solutions and long term partnering efforts must be maintained. Weapons are too expensive and the security environment is too complex for any nation to pursue unilateral solutions.

USAFE's five year engagement plan with Bulgaria will support a broader vision of the future being developed by the Center for Civil-Military Relations. ${ }^{2}$ These types of $\mathrm{mid} /$ long term strategy studies will pay big dividends.

Successful long term air capability development also requires cross-functional transformation. Force development is also crucial - the concept of centralized control and decentralized execution which is critical to NATO air effectiveness can best be achieved through empowered, educated, well trained, professional airmen in every rank. These airmen must be allowed to operate within the guidelines contained in regulations designed for the all-volunteer force you are growing in the next decade, as they replace the conscript force of twenty years ago.

Changes and investments in infrastructure and logistics must precede the acquisition of new weapon systems, otherwise the sustainability of new combat capabilities is put at risk. Airfields, airspace, ranges, munitions storage, fuel and lubricants facilities, operations facilities, C2 nodes, all must be considered in the acquisition process. I would recommend you consider NATO interoperability, how easily a system can be sustained, and whether or not it can be deployed before making a purchase decision.

Successful international military partnering requires the same investment in total force transformation. Well trained airmen, robust infrastructure, and interoperable weapons system are key to alliance effectiveness and our collective security - that is the only real security. 


\section{Conclusion}

One of my favorite Greek philosophers was Heraclitus; he reminds us that "You cannot step in the same river twice.” The world is constantly changing and accelerating that change each year through technology. If we want successful acquisition programs, military leaders have to consider much more than just which system to buy we have to be cognizant of the "political \& economic grand system" in which we operate. By focusing on the long term solutions to security challenges Bulgaria will ensure that it moves down a path that enhances its ability to act as a sovereign nation and supports collective defense.

\section{Notes:}

${ }^{1}$ See, for example, the Autobiography of 2001 Nobel prize laureate Joseph E. Stieglitz, <http://nobelprize.org/nobel_prizes/economics/laureates/2001/stiglitz-autobio.html>, and the references therein.

${ }^{2}$ Center for Civil-Military Relations, Naval Postgraduate School, Monterey, Caloifornia, $<$ www.ccmr.org/public/home.cfm>. 